Abstracta Iranicacta Iranica

Revue bibliographique pour le domaine irano-aryen

Volume 24 | 2003

Comptes rendus des publications de 2001

\title{
TārīH-i Jahāngušā. Éd. Muḥammad Qazvīnī, Tehrān, Naqš-i qalam, 1379/2000, 3 vol.
}

\section{Denise Aigle}

\section{(2) OpenEdition}

\section{Journals}

Édition électronique

URL : http://journals.openedition.org/abstractairanica/34611

ISSN : 1961-960X

Éditeur :

CNRS (UMR 7528 Mondes iraniens et indiens), Éditions de l'IFRI

Édition imprimée

Date de publication : 15 mai 2003

ISSN : 0240-8910

\section{Référence électronique}

Denise Aigle, "Tārīh-i Jahāngušā. Éd. Muhammad Qazvīnī, Tehrān, Naqš-i qalam, 1379/2000, 3 vol. », Abstracta Iranica [En ligne], Volume 24 | 2003, document 202, mis en ligne le 05 janvier 2010, consulté le 25 septembre 2020. URL : http://journals.openedition.org/abstractairanica/34611

Ce document a été généré automatiquement le 25 septembre 2020.

Tous droits réservés 


\title{
TārīH-i Jahāngušā. Éd. Muhammad Qazvīnī, Tehrān, Naqš-i qalam, 1379/2000, 3 vol.
}

\author{
Denise Aigle
}

1 Ces trois volumes sont une réimpression intégrale de la première édition du texte, parue en 1912 dans la série E. J. W. Gibb Memorial Series, vol. XVI. Cette réédition est très bienvenue car il était aujourd'hui impossible de se procurer ce texte si important pour l'histoire de la première période mongole.

2 Juvaynī (ca. 1226-1283) était issu d'une famille de notables du Khorâssân qui avaient tenu de hautes charges sous les Seldjoukides et les Khwârazmshâhs. Ils se mirent au service des Mongols après que ces derniers eurent conquis l'Iran oriental. 'Ațā' Malik a séjourné en Mongolie de 1249 à 1251 et, après un bref retour dans ses terres, une seconde fois de 1251 à 1253.

Le Tārīu-i Jahāngušă, commencé à Qara Qorum en 1252 ou 1253, est le produit de son temps : le récit manque parfois d'objectivité, mais le témoignage de son auteur est de première importance car il est le seul historien persan à avoir séjourné en Mongolie. Sa chronique est du plus grand intérêt pour le récit des conquêtes mais également d'un point de vue d'histoire culturelle et religieuse. En effet, il a observé à la cour mongole nombre de coutumes, de tabous et de pratiques. Son récit peut être comparé à ceux des missionnaires latins envoyés dans l'empire mongol, Jean de Plan Carpin et Guillaume de Rubrouck, "ethnologues» avant la lettre. Pour cette raison, Juvaynī est l'une des principales sources à laquelle puisèrent les historiens mamelouks et l'historien de langue syriaque, Bar Hebraeus. Outre son intérêt historique, la chronique de Juvaynī, dans laquelle sont insérés des poèmes en arabe, en persan, des vers de sa propre composition, est également un texte d'intérêt littéraire, témoin du style et de la prose de son époque.

Cette édition est précédée d'une introduction sur la biographie de l'éditeur du texte, Muhammad Qazvīnī (pp. 4-13), suivie d'une liste de ses travaux (pp. 4-10). 
5 Nous profitons de cette notice pour signaler la réédition de la traduction du texte de Juvaynī par J. A. Boyle qui était parue en 1958: Ata-Malik Juvayni, Genghis Khan. The History of the World-Conqueror, trans. and ed. J. A. Boyle, with an introduction by David O. Morgan, Manchester, University Press and Seattle, University of Washington Press, 1997, lxvii + 763 p., 3 maps. Voir le compte rendu par Charles Melville dans Iranian Studies, vol. 32/3 (1999), pp. 435-437.

INDEX

Thèmes : 11.1.1. Littérature persane classique

AUTEURS

DENISE AIGLE

IFEAD - Damas 